\title{
PERAN MODERASI MINDFULNESS DALAM HUBUNGAN ANTARA INTENSITAS PENGGUNAAN INSTAGRAM DAN KESEPIAN PADA DEWASA MUDA
}

\author{
Tyas Apti Salsabila ${ }^{1}$, Riana Sahrani $^{2}$ \\ ${ }^{1}$ Program Studi Sarjana Psikologi, Universitas Tarumanagara, Jakarta \\ Email: tyas.705170255@stu.untar.ac.id \\ ${ }^{2}$ Fakultas Psikologi, Universitas Tarumanagara, Jakarta \\ Email: rianas@fpsi.untar.ac.id
}

Masuk : 28-01-2021, revisi: 04-08-2021, diterima untuk diterbitkan :04-08-2021

\begin{abstract}
Loneliness is a feeling of emptiness that a person feels as a result of a lack of intimacy with others. The development of social media technology is also one of the factors that affect a person's loneliness. Results from previous research have shown that the use of social media can make a person lonely. To reduce feelings of loneliness, one must have mindfulness. The purpose of this study was to test the role of mindfulness moderation against the intensity of relationships of Instagram use and loneliness. The research uses non-experimental quantitative methods. Measuring instruments used in this study are UCLA Loneliness scale version 3, Instagram usage intensity measuring instrument, and Kentucky Inventory of Mindfulness Skills. The participants of this study were 544 people who are Indonesian residents aged 20-40 years active users of Instagram.The results of this study show that there is no significant relationship between the intensity of Instagram use and loneliness, so the role of mindfulness moderation cannot be proven.
\end{abstract}

Keywords: Loneliness, social media intensity, Instagram, mindfulness, young adults.

\begin{abstract}
ABSTRAK
Kesepian merupakan perasaan hampa yang dirasakan seseorang akibat dari kurangnya keintiman dengan orang lain. Perkembangan teknologi sosial media juga menjadi salah satu faktor yang memengaruhi rasa kesepian seseorang. Hasil dari penelitian sebelumnya menunjukkan bahwa penggunaan sosial media dapat menyebabkan seseorang menjadi kesepian. Untuk mengurangi perasaan kesepian, seseorang harus memiliki kesadaran dan sikap mindfulness. Tujuan penelitian ini adalah ingin menguji peran moderasi mindfulness terhadap hubungan intensitas penggunaan Instagram dan kesepian. Penelitian menggunakan metode kuantitatif non-eksperimental. Alat ukur yang digunakan pada penelitian ini adalah UCLA Loneliness scale version 3, alat ukur intensitas penggunaan Instagram, dan Kentucky Inventory of Mindfulness Skills. Partisipan penelitian ini sebanyak 544 orang yang merupakan penduduk Indonesia berusia 20-40 tahun pengguna aktif Instagram. Hasil penelitian ini menunjukkan bahwa tidak terdapat hubungan signifikan antara intensitas penggunaan Instagram dan kesepian, sehingga peran moderasi mindfulness tidak dapat dibuktikan.
\end{abstract}

Kata Kunci: Kesepian, intensitas penggunaan sosial media, Instagram, mindfulness, dewasa muda.

\section{PENDAHULUAN}

\section{Latar Belakang}

Survei awal tahun yang dilakukan oleh Ipsos (2020) di beberapa negara menunjukkan lebih dari 50\% partisipan merasa dirinya akan menjadi lebih kesepian selama tahun 2020. Sebuah survei di Amerika juga mengemukakan, pada tahun 2019 lebih dari 60\% dewasa merasakan kesepian dan hal ini menunjukkan peningkatan dari tahun sebelumnya yaitu, sekitar 54\% orang dewasa (Cigna, 2020). Di Indonesia sendiri, hampir 60\% individu berusia 30-59 tahun merasakan kesepian (Peltzer \& Pengpid, 2019). Hal ini menunjukkan bahwa kesepian merupakan salah satu permasalahan genting yang sedang dialami oleh penduduk dunia termasuk Indonesia.

Kesepian digambarkan sebagai sebuah tekanan psikologis, perasaan tidak berdaya, dan putus asa (Bell \& Daly, 1985). Kesepian juga didefinisikan sebagai kekosongan yang dirasakan oleh seseorang akibat kurangnya membuka diri dan membangun keintiman dengan orang lain (Solano 
et al., 1982; Vodanovich, 2003). Kesepian dapat dipengaruhi oleh banyak sekali faktor, salah satunya adalah penggunaan sosial media (Hunt et al., 2018; Yang, 2016). Beberapa penelitian sebelumnya menunjukkan bahwa penggunaan sosial media dengan intensitas tinggi dapat menyebabkan kesepian. Seperti penelitian yang dilakukan oleh Hunt et al. terhadap 143 mahasiswa University of Pennsylvania, penelitian ini menunjukkan bahwa intensitas penggunaan sosial media Facebook, Instagram, dan Snapchat terbukti dapat meningkatkan rasa kesepian secara signifikan (Hunt et al., 2018).

Berdasarkan fenomena tersebut, terbukti bahwa intensitas penggunaan sosial media menyebabkan seseorang merasakan kesepian. Namun pernyataan ini dibantah oleh beberapa penelitian yang menyatakan kebalikannya. Seperti penelitian yang dilakukan oleh Pittman dan Reich, hasil dari penelitian ini menjelaskan bahwa intensitas penggunaan sosial media Instagram dan Snapchat memiliki korelasi negatif terhadap kesepian (Pittman \& Reich, 2016). Selain penelitian yang menjelaskan bahwa penggunaan intensitas sosial media memiliki korelasi dengan kesepian, terdapat pula penelitian yang menentang hasil ini. Menurut penelitian yang dilakukan oleh Phu \& Gow (2019), perasaan kesepian juga tidak memiliki berhubungan dengan intensitas penggunaan sosial media. Selanjutnya, sebuah penelitian dilakukan terhadap 157 partisipan dan hasil penelitian menunjukkan kesepian tidak terpengaruhi oleh penggunaan sosial media (Yavich et al., 2019).

Perbedaan hasil penelitian-penelitian ini juga menjadikan keterkaitan antara penggunaan sosial media dan kesepian perlu dikaji kembali. Namun jika terbukti penggunaan sosial media menyebabkan kesepian, pengguna sosial media menjadi terancam mengalami dampak dari perasaan kesepian. Perasaan hampa dan terisolasi yang dirasakan seseorang dapat berdampak terhadap kesehatan fisik seperti meningkatkan resiko penyakit jantung koroner, darah tinggi, dan gagal jantung (Luo et al., 2012; Patterson \& Veenstra, 2010). Selain itu, kesepian juga dapat menyebabkan gangguan psikologis seperti depresi, gangguan tidur, kecemasan (Jaremka et al., 2014; Moeller \& Seehuus, 2019). Salah satu cara untuk terhindar dari dampak negatif tekanan psikologis kesepian, seseorang harus memiliki sikap mindfulness yang baik (Creswell et al., 2012). Mindfulness merupakan kemampuan seseorang untuk merasakan sensasi dari emosi dan pikiran yang diterima oleh diri secara sadar dan perhatian (Charoensukmongkol, 2016). Menurut Siegel et al., mindfulness dapat memberikan perubahan positif terhadap seseorang dalam menyikapi masalah dan pengalaman (dalam Kabat-Zinn, 2018). Mindfulness juga mengurangi tekanan dan meningkatkan kesejahteraan psikologis seseorang (Bishop et al., 2004; Leroy et al., 2013). Penelitian Y. Jin et al. (2020) menunjukkan adanya hubungan negatif signifikan antara kesepian dengan mindfulness (Y. Jin et al., 2020). Selain itu, penelitian yang dilakukan oleh Creswell et al. (2012) juga membuktikan bahwa pengembangan dan pelatihan mindfulness dapat mengurangi stress penyebab kesepian (Creswell et al., 2012). Hasil penelitian yang dilakukan oleh Charoensukmongkol (2016), partisipan yang menggunakan sosial media namun memiliki mindfulness tinggi membuat seseorang terhindar dari perasaan tertekan, stress, dan burnout pada pekerjaan mereka (Charoensukmongkol, 2016).

Berdasarkan penjelasan di atas, peneliti tertarik untuk melihat peranan mindfulness sebagai moderator dalam hubungan intensitas sosial media dan kesepian. Pada penelitian ini, mindfulness diharapkan dapat menjadi kemampuan seseorang untuk mengontrol penggunaan sosial media. Di sisi lain, mindfulness juga diharapkan menjadi aspek yang mampu menghindarkan seseorang dari perasaan dan pengalaman tidak menyenangkan, yaitu kesepian. 


\section{Rumusan Masalah}

Bagaimana peranan mindfulness sebagai moderator dalam hubungan intensitas penggunaan Instagram dan kesepian pada dewasa muda?

\section{METODE PENELITIAN}

Metode dalam penelitian ini adalah kuantitatif. Teknik pengambilan data penelitian menggunakan nonprobability sampling, yaitu purposive sampling. Partisipan pada penelitian ini memiliki kriteria khusus yaitu, dewasa muda berusia 12-16 tahun, pengguna aktif instagram, dan telah memiliki akun Instagram lebih dari 6 bulan. Tidak ada batasan suku bangsa, ras, agama, jenis kelamin, maupun domisili. Pengambilan data dilakukan secara daring menggunakan kuesioner dalam bentuk Google Form.

\section{Alat ukur}

Penelitian ini menggunakan University California of Los Angeles (UCLA) Loneliness Scale Version 3 untuk mengukur kesepian. Alat ukur ini disusun oleh Russel et al. dan diterjemahkan oleh Fatriani (2019). Alat ukur unidimensional ini berisi 20 butir pertanyaan. Setiap butir memiliki 4 buah pilihan jawaban yaitu, "tidak pernah", "jarang", "sering”, dan "sangat sering". Semakin tinggi skor yang didapatkan oleh partisipan, maka semakin tinggi tingkat kesepian pada partisipan tersebut.

Selanjutnya, alat ukur Intensitas penggunaan Instagram yang diadaptasi dari Sukmaraga (2018). Alat ukur ini berdasar pada teori Tubbs dan Moss pengukuran intensitas penggunaan sosial media Instagram dalam dua aspek yaitu, frekuensi dan durasi. Alat ukur unidimensional ini terdiri dari empat butir yang mengukur aspek penggunaan sosial media Instagram dalam satu hari dan satu minggu.

Untuk mengukur mindfulness peneliti menggunakan Kentucky Inventory of Mindfulness Skills (KIMS) yang disusun oleh Baer et al. dan telah diterjemahkan oleh Widodo (2015). Alat ukur ini yang terdiri dari 39 butir pertanyaan dan memiliki 4 dimensi yaitu observing, describing, act with awareness, dan accept without judgement. Setiap butir pertanyaan memiliki 5 jawaban yang berdasar pada skala likert. Partisipan dapat memilih jawaban "tidak pernah", "jarang", "kadangkadang", "sering", dan "sangat sering". Semakin tinggi skor yang didapatkan, maka tingkat mindfulness dari partisipan tersebut akan semakin tinggi.

\section{HASIL DAN PEMBAHASAN \\ Hasil dan Analisis Data Utama}

Penelitian ini memiliki total 544 partisipan, dengan rincian 102 orang berjenis kelamin laki-laki dan 442 orang berjenis kelamin perempuan. Jika berdasarkan usia, 96.3\% partisipan berada dalam kelompok usia 20-25 tahun. Selain itu, $81.3 \%$ partisipan berprofesi sebagai mahasiswa dan $66 \%$ partisipan telah menggunakan Instagram lebih dari 5 tahun.

Peneliti melakukan pengujian korelasi terhadap variabel intensitas penggunaan Instagram dan kesepian. Jika berdasarkan uji normalitas sebelumnya, data penelitian ini terdistribusi normal sehingga pengujian korelasi menggunakan pearson correlation. Hasil uji korelasi antara intensitas penggunaan Instagram dan kesepian menunjukkan bahwa $r(544)=0,020 ; \mathrm{p}=0,641>0,05$. Sehingga dapat dijelaskan bahwa tidak terdapat hubungan yang signifikan antara intensitas penggunaan Instagram dan kesepian. Rincian data tertera pada Tabel 1. 


\section{Tabel 1}

Uji Korelasi Intensitas Penggunaan Instagram dan Kesepian

\begin{tabular}{ccc}
\hline Hubungan & Koefisien Korelasi $(\boldsymbol{r})$ & Sig. (2-tailed) \\
\hline $\begin{array}{c}\text { Intensitas Penggunaan Instagram } \\
<=>\text { Kesepian }\end{array}$ & 0.020 & 0.641 \\
\hline
\end{tabular}

Selanjutnya, peneliti juga melakukan uji korelasi antara mindfulness dan kesepian. Hasil uji korelasi antara mindfulness dimensi observation dan kesepian menunjukkan bahwa $r(544)=-$ 0,$038 ; p=0,380>0,05$. Berdasarkan hasil ini dapat dijelaskan bahwa tidak ada hubungan yang signifikan antara mindfulness dimensi observation dan kesepian. Selanjutnya, hasil uji korelasi antara mindfulness dimensi describing dan kesepian menunjukkan nilai $r(544)=-0,499 ; p=0,000$ $<0,05$. Berdasarkan hasil ini dapat dijelaskan adanya hubungan negatif signifikan yang sedang atau cukup antara mindfulness dimensi describing dan kesepian. Hal ini menunjukkan bahwa semakin tinggi mindfulness dimensi describing, maka tingkat kesepian akan semakin rendah dan juga sebaliknya. Uji korelasi antara kesepian dan mindfulness dimensi act with awareness menunjukkan nilai $r(544)=-0,361 ; \mathrm{p}=0,000<0,05$. Hasil ini menjelaskan adanya hubungan negatif signifikan yang lemah antara mindfulness dimensi act with awareness dan kesepian. Maka semakin tinggi mindfulness dimensi act with awareness, maka tingkat kesepian akan semakin rendah dan juga sebaliknya. Hasil uji korelasi kesepian dan mindfulness dimensi accept without judgement menunjukkan nilai $r(544)=-0,371 ; p=0,000<0,05$. Hasil ini menjelaskan adanya hubungan negatif signifikan yang lemah antara mindfulness dimensi accept without judgement dan kesepian. Hal ini menunjukkan bahwa semakin tinggi mindfulness dimensi accept without judgement, maka tingkat kesepian akan semakin rendah. Rincian data tertera pada tabel 2.

\section{Tabel 2}

Uji Korelasi Mindfulness dan Kesepian

\begin{tabular}{ccc}
\hline Hubungan & Koefisien Korelasi $(\boldsymbol{r})$ & Sig. (2-tailed) \\
\hline $\begin{array}{c}\text { Mindfulness dimensi } \text { observation } \\
<=>\text { Kesepian }\end{array}$ & 0.038 & 0.380 \\
\hline $\begin{array}{c}\text { Mindfulness dimensi describing } \\
<=>\text { Kesepian }\end{array}$ & $-.0499^{* *}$ & 0.000 \\
\hline $\begin{array}{c}\text { Mindfulness dimensi act } \text { with } \\
\text { awareness }<=>\text { Kesepian }\end{array}$ & $-0.361^{* *}$ & 0.000 \\
\hline $\begin{array}{c}\text { Mindfulness } \text { dimensi accept } \\
\text { without judgement }<=>\text { Kesepian }\end{array}$ & $-0.371^{* *}$ & 0.000 \\
\hline
\end{tabular}

\section{Hasil dan Analisis Data Tambahan}

Berdasarkan analisis data tambahan, partisipan pada penelitian ini memiliki tingkat kesepian yang sedang hingga rendah. Selain itu, tidak terdapat perbedaan tingkat kesepian jika ditinjau dari jenis kelamin, usia, pekerjaan, dan lama kepemilikan akun Instagram. Begitu pula dengan variabel intensitas penggunaan Instagram. Partisipan pada penelitian ini memiliki rata-rata intensitas penggunaan Instagram yang sedang hingga tinggi. Tidak ditemukan perbedaan tingkat intensitas penggunaan Instagram jika ditinjau dari jenis kelamin, usia, dan lama kepemilikan akun Instagram. Namun hasil menunjukkan bahwa terdapat perbedaan signifikan jika intensitas penggunaan Instagram ditinjau dari tipe pekerjaan partisipan $(\mathrm{p}=0.003, \mathrm{~F}=2.962)$. Pada variabel mindfulness, tidak terdapat perbedaan antara kelompok mindfulness dimensi observation, describing, dan act with awareness jika ditinjau dari usia, jenis kelamin, pekerjaan, dan lama kepemilikan akun Instagram. Namun, penelitian ini menemukan adanya perbedaan signifikan tingkat mindfulness dimensi accept without judgement jika ditinjau dari kelompok usia ( $\mathrm{p}=0.017, \mathrm{~F}=3.411)$. Perbedaan 
juga terlihat pada mindfulness dimensi accept without judgement jika ditinjau dari lama kepemilikan akun Instagram ( $\mathrm{p}=0.021, \mathrm{~F}=3.272)$.

\section{Pembahasan}

Variabel moderator yaitu mindfulness memiliki hubungan negatif yang signifikan dengan kesepian. Namun, hubungan variabel bebas (intensitas penggunaan Instagram) dan variabel terikat (kesepian) tidak signifikan. Jadi dapat disimpulkan bahwa tidak ada hubungan antara intensitas penggunaan Instagram dan kesepian, sehingga tidak dapat dilanjutkan dengan uji peran dan uji moderasi. Pertama, hasil pada penelitian ini tidak dapat membuktikan peran moderasi mindfulness dalam hubungan intensitas penggunaan Instagram dan kesepian. Hal ini dikarenakan variabel bebas atau intensitas penggunaan Instagram dan variabel terikat atau kesepian tidak memiliki hubungan yang signifikan. Hubungan tidak signifikan antara dua variabel ini sejalan dengan penelitian yang dilakukan oleh Yavich dan rekan-rekannya. Hasilnya terbukti bahwa Intensitas penggunaan sosial media tidak berkaitan dengan perasaan kesepian secara signifikan (Yavich et al., 2019). Menurut B. Jin (2013), kesepian yang dirasakan seseorang tidak memiliki hubungan dengan intensitas penggunaan sosial media. Hubungan antara intensitas penggunaan Instagram dan kesepian tidak signifikan dipengaruhi oleh partisipan yang merupakan penduduk Indonesia dan memiliki kultur seperti negara Asia lainnya. Budaya berkomunikasi, pertemanan dan kekeluargaan yang kuat dengan orang lain dapat menghindarkan seseorang dari perasaan kesepian. Hal ini sejalan dengan hasil penelitian sebelumnya yang menjelaskan negara dengan budaya kolektif seperti negara-negara Asia, rata-rata memiliki tingkat kesepian yang rendah dikarenakan lingkungan keluarga dan pertemanan yang erat (Lykes \& Kemmelmeier, 2014; Ng \& Northcott, 2015). Gambaran kesepian pada partisipan yang sedang hingga rendah juga membuktikan bahwa Indonesia dengan kultur Asia tidak mudah terpengaruh oleh kesepian.

Kedua, Mindfulness secara hampir keseluruhan dimensi, yaitu dimensi describing, act with awareness, dan accept without judgement memiliki hubungan negatif yang signifikan dengan kesepian. Hal ini menunjukan bahwa semakin tinggi tingkat mindfulness maka semakin rendah perasaan kesepian yang dirasakan oleh seseorang. Hubungan negatif signifikan juga dilaporkan pada penelitian yang dilakukan oleh Y Jin et al. tahun 2020. Hasil penelitian ini menunjukkan bahwa semakin tinggi sifat mindfulness atau kesadaran akan tindakan diri seseorang, maka semakin rendah kesepian yang dirasakan oleh seseorang (Y. Jin et al., 2020). Jika ketiga dimensi ini dibandingkan, dimensi describing memiliki nilai koefisien korelasi yang paling tinggi ( $r=-$ $0,499)$ jika dibandingkan dengan dua dimensi lainnya, yaitu act with awareness $(r=-0,361)$ dan accept without judgement $(r=-0,371)$. Berdasarkan nilai koefisien korelasi ini, dapat disimpulkan bahwa mindfulness dimensi describing memiliki hubungan yang lebih kuat dibandingkan dimensi lainnya terhadap kesepian. Hasil ini sejalan dengan penelitian sebelumnya bahwa sikap mindfulness seperti sadar dalam bertindak, mudah beradaptasi, menahan diri dari hal negatif, dan pelatihan mindfulness dapat mengurangi perasaan kesepian pada seseorang (Baer et al., 2004; Creswell et al., 2012). Creswell et al. juga menjelaskan bahwa terdapat hubungan negatif antara kesepian dan mindfulness dengan dimensi describing yang memiliki koefisien korelasi lebih tinggi dibandingkan dimensi lainnya (2012).

Ketiga, kesepian tidak memiliki perbedaan signifikan jika dibandingkan dalam kelompok jenis kelamin, usia, pekerjaan, dan lama kepemilikan akun Instagram. Kesepian berdasarkan jenis kelamin mungkin saja tidak bisa dibuktikan karena ketidakseimbangan jumlah partisipan perempuan dan laki-laki. Penelitian ini memiliki partisipan perempuan sebesar $81,2 \%$ dari total partisipan keseluruhan. Perbedaan pada kelompok usia juga tidak dapat dibuktikan. Hal ini sejalan dengan hasil penelitian yang menjelaskan bahwa kelompok usia tidak memiliki hubungan dengan 
kesepian pada partisipan berusia dewasa (Maes et al., 2019). Tidak adanya perbedaan pada kelompok-kelompok di atas juga berdasarkan pada faktor-faktor yang memengaruhi kesepian. Faktor-faktor internal yang memengaruhi seperti kepribadian seseorang, rasa malu, self esteem yang rendah, kurang kegiatan, dan kebiasaan merokok (Bian \& Leung, 2015; Shankar et al., 2011; Vanhalst et al., 2013). Selain itu, terdapat juga faktor eksternal seperti hubungan interpersonal dengan orang lain, attachment dengan pasangan, dan pernah menjadi korban perundungan (Cao et al., 2020; Givertz et al., 2013). Sehingga perasaan kesepian pada seseorang dapat dipengaruhi oleh banyak faktor dan berdasarkan keadaan individu masing-masing.

Keempat, gambaran penelitian ini menunjukkan bahwa rata-rata tingkat intensitas penggunaan Instagram adalah sedang hingga tinggi. Hal ini juga sejalan dengan survei yang dilakukan oleh Asosiasi Penyelenggara Jasa Internet, bahwa intensitas penggunaan internet pada dewasa muda merupakan salah satu yang tertinggi, walaupun masih dibawah kelompok umur remaja (APJII, 2018). Penelitian ini juga menjelaskan bahwa terdapat perbedaan intensitas penggunaan Instagram yang signifikan antar kelompok pekerjaan. Hasil ini menjelaskan bahwa perbedaan pekerjaan partisipan memengaruhi intensitas penggunaan. Hasil ini juga didukung dengan hasil penelitian sebelumnya yang menyatakan bahwa, individu dengan profesi perawat juga menggunakan sosial media sebagai sarana edukasi mengenai profesi perawat (Alharbi et al., 2020). Perbedaan kebutuhan pemakaian sosial media juga memengaruhi intensitas penggunaan sosial media pada individu dengan pekerjaan tertentu. Salah satunya adalah karyawan bagian marketing yang memanfaatkan sosial media sebagai personal branding dan juga promosi untuk perusahaan terkait (Jacobson, 2020).

Kelima, gambaran penelitian ini memperlihatkan bahwa rata-rata mindfulness pada partisipan adalah sedang hingga tinggi. Berdasarkan mean empiris, mindfulness dimensi observation memiliki mean empiris terbesar diantara dimensi lainnya. Hal ini menunjukkan bahwa rata-rata partisipan lebih menyadari sensasi, suara, serta durasi dari fenomena yang sedang berlangsung. Mindfulness dimensi accept without judgement memiliki perbedaan signifikan antar kelompok usia. Namun, secara keseluruhan dimensi tidak terdapat perbedaan mindfulness antara kelompok pekerjaan dan jenis kelamin. Kesadaran seseorang akan fenomena diri yang sedang terjadi atau sikap mindfulness lebih dipengaruhi oleh perbedaan usia. Semakin matang usia individu, maka mindfulness dan proses kognitif individu tersebut akan semakin baik (Whitfield et al., 2020). Namun hal ini tentu harus diseimbangkan dengan pelatihan sikap mindfulness (Creswell et al., 2012; Whitfield et al., 2020). Mindfulness dimensi accept without judgement memiliki perbedaan signifikan antar kelompok lama kepemilikan akun Instagram. Hal ini juga dibuktikan bahwa kepemilikan akun sosial media dan lama pemakaian sosial media dapat membantu seseorang terhindar dari gangguan psikologis, selama digunakan dengan bijak dan penuh sikap mindfulness (Charoensukmongkol, 2016).

\section{KESIMPULAN DAN SARAN}

Variabel moderator yaitu mindfulness memiliki hubungan negatif yang signifikan dengan kesepian. Namun, hubungan intensitas penggunaan Instagram dan kesepian tidak menunjukkan hasil signifikan. Tidak adanya hubungan antara intensitas penggunaan Instagram dan kesepian menyebabkan pengolahan data tidak dapat dilanjutkan dengan uji peran dan uji moderasi. Bukti lain dari penelitian ini adalah semakin tinggi sikap mindfulness seseorang, maka semakin rendah seseorang akan merasakan kesepian. 
Secara teoritis, saran peneliti untuk bidang psikologi sosial dan komunikasi adalah memperdalam perilaku pengguna sosial media Instagram, seperti perilaku pengguna Instagram yang sering mengunggah konten atau perilaku pengguna yang hanya menggunakan Instagram untuk hiburan semata. Dengan menguji perbedaan perilaku di atas, mungkin saja dapat memperjelas faktor-faktor penggunaan Instagram yang bisa jadi memengaruhi kesepian. Selain itu akan lebih baik jika penelitian selanjutnya mengkaji mengenai alasan seseorang dalam menggunakan sosial media. Peneliti menyarankan untuk mempersempit rentang usia partisipan dan menyeimbangkan jumlah partisipan laki-laki dan perempuan. Penelitian selanjutnya juga dapat melakukan replikasi dari penelitian ini dengan beberapa perubahan seperti memfokuskan partisipan pada kategori remaja atau memilih partisipan yang mengalami adiksi sosial media. Selain itu, penelitian selanjutnya juga akan lebih baik jika mencoba metode penelitian lainnya seperti kualitatif dan eksperimen. Metode eksperimen seperti, pelatihan mindfulness untuk mengurangi penggunaan sosial media dan mengurangi kesepian. Selain itu, penelitian selanjutnya sekiranya lebih menelusuri lebih lanjut variabel yang memungkinkan untuk menjadi variabel bebas, mediator, ataupun moderator terhadap kesepian. Pergeseran hasil-hasil penelitian sebelumnya mengenai sosial media dapat berpotensi untuk menghasilkan teori baru dalam membantu seseorang terhindar dari kesepian serta mengembangkan ilmu psikologi sosial dan komunikasi. Penelitian mengenai dampak sosial media juga dapat diperluas terhadap platform sosial media lainnya seperti Youtube, Twitter, TikTok, dan lain-lain.

Secara praktis, saran peneliti bagi masyarakat luas adalah untuk menggunakan sosial media dengan bijak. Pemakaian sosial media yang bijak dapat memberikan lebih banyak manfaat bagi pribadi seseorang. Walaupun hasil penelitian menunjukkan bahwa intensitas penggunaan Instagram tidak berhubungan dengan kesepian, bukan berarti penggunaan sosial media tidak memiliki dampak negatif terhadap kesehatan mental. Maka dari itu peneliti menyarankan agar pengguna aktif sosial media tidak menggunakan sosial media secara berlebihan dan lebih memilih konten-konten bermanfaat untuk pengembangan diri. Masyarakat, terutama dewasa muda juga penting untuk menyadari pentingnya sikap mindfulness. Untuk membangun mindfulness dalam diri juga bukan merupakan proses yang instan. Peneliti menyarankan kepada dewasa muda untuk melatih sikap mindfulness dengan cara seperti: lebih memfokuskan satu kegiatan pada satu waktu, menikmati setiap proses kegiatan yang sedang berlangsung, meditasi, dan selalu berpikiran positif.

\section{Ucapan Terima Kasih (Acknowledgement)}

Kami mengucapkan terima kasih kepada Fakultas Psikologi Universitas Tarumanagara dan juga seluruh partisipan yang telah bersedia meluangkan waktunya untuk mengisi survei penelitian ini.

\section{REFERENSI}

Alharbi, M., Kuhn, L., \& Morphet, J. (2020). Undergraduate nursing students' adoption of the professional identity of nursing through social media use: A qualitative descriptive study. Nurse Education Today, 92, 104488. https://doi.org/10.1016/j.nedt.2020.104488

Asosiasi Penyelenggara Jasa Internet Indonesia. (2018, Mei 18). Hasil survei penetrasi dan perilaku pengguna internet Indonesia 2018. https://www.apjii.or.id/content/utama/39

Baer, R. A., Smith, G. T., \& Allen, K. B. (2004). Assessment of mindfulness by self-report: The Kentucky inventory of mindfulness skills. Assessment, 11(3), 191-206. https://doi.org/10.1177/1073191104268029

Bell, R. A., \& Daly, J. A. (1985). Some communicator correlates of loneliness. Southern Speech Communication Journal, 50(2), 121-142. https://doi.org/10.1080/10417948509372627 
Bian, M., \& Leung, L. (2015). Linking loneliness, shyness, smartphone addiction symptoms, and patterns of smartphone use to social capital. Social Science Computer Review, 33(1), 6179. https://doi.org/10.1177/0894439314528779

Bishop, S. R., Kraemer, H. C., Turner, J. A., Anderson, M. L., Balderson, B. H., Cook, A. J., Sherman, K. J., \& Cherkin, D. C. (2004). Mindfulness: A proposed operational definition. Clinical Psychology: Science and Practice, 157(3), 230-241. https://doi.org/10.1093/clipsy/bph077

Cao, Q., Xu, X., Xiang, H., Yang, Y., Peng, P., \& Xu, S. (2020). Bullying victimization and suicidal ideation among Chinese left-behind children: Mediating effect of loneliness and moderating effect of gender. Children and Youth Services Review, 111. https://doi.org/10.1016/j.childyouth.2020.104848

Charoensukmongkol, P. (2016). Mindful facebooking: The moderating role of mindfulness on the relationship between social media use intensity at work and burnout. Journal of Health Psychology, 21(9), 1966-1980. https://doi.org/10.1177/1359105315569096

Cigna. (2020, n.d). Loneliness is at epidemic levels in America. Cigna. https://www.cigna.com/about-us/newsroom/studies-and-reports/combatting-loneliness/

Creswell, J. D., Irwin, M. R., Burklund, L. J., Lieberman, M. D., Arevalo, J. M. G., Ma, J., Breen, E. C., \& Cole, S. W. (2012). Mindfulness-based stress reduction training reduces loneliness and pro-inflammatory gene expression in older adults: A small randomized controlled trial. Brain, Behavior, and Immunity, 26(7), 1095-1101. https://doi.org/10.1016/j.bbi.2012.07.006

Fatriani, D. N. (2019). Hubungan dukungan sosial dengan kesepian pada mahasiswa tahun pertama yang merantau di universitas $x$ Jakarta [Skripsi tidak dipublikasikan].Universitas Tarumanagara.

Givertz, M., Woszidlo, A., Segrin, C., \& Knutson, K. (2013). Direct and indirect effects of attachment orientation on relationship quality and loneliness in married couples. Journal of Social and Personal Relationships, 30(8), 1096-1120. https://doi.org/10.1177/0265407513482445

Hunt, M. G., Marx, R., Lipson, C., \& Young, J. (2018). No more FOMO: Limiting social media decreases loneliness and depression. Journal of Social and Clinical Psychology, 37(10), 751-768. https://doi.org/10.1521/jscp.2018.37.10.751

Ipsos. (2020, Maret 2). Global predictions for 2020. Ipsos. https://www.ipsos.com/en/ipsosupdate-march-2020

Jacobson, J. (2020). You are a brand: Social media managers' personal branding and "the future audience." Journal of Product and Brand Management, 29(6), 715-727. https://doi.org/10.1108/JPBM-03-2019-2299

Jaremka, L. M., Andridge, R. R., Fagundes, C. P., Alfano, C. M., Povoski, S. P., Lipari, A. M., Agnese, D. M., Arnold, M. W., Farrar, W. B., Yee, L. D., Carson, W. E., Bekaii-Saab, T., Martin, E. W., Schmidt, C. R., \& Kiecolt-Glaser, J. K. (2014). Pain, depression, and fatigue: Loneliness as a longitudinal risk factor. Health Psychology, 33(9), 948-957. https://doi.org/10.1037/a0034012

Jin, B. (2013). How lonely people use and perceive Facebook. Computers in Human Behavior, 29(6), 2463-2470. https://doi.org/10.1016/j.chb.2013.05.034

Jin, Y., Zhang, M., Wang, Y., \& An, J. (2020). The relationship between trait mindfulness, loneliness, regulatory emotional self-efficacy, and subjective well-being. Personality and $\begin{array}{lll}\text { Individual } \quad \text { Differences, } & 154 \text { (October }\end{array}$ https://doi.org/10.1016/j.paid.2019.109650 
Leroy, H., Anseel, F., Dimitrova, N. G., \& Sels, L. (2013). Mindfulness, authentic functioning, and work engagement: A growth modeling approach. Journal of Vocational Behavior, 82(3), 238-247. https://doi.org/10.1016/j.jvb.2013.01.012

Luo, Y., Hawkley, L. C., Waite, L. J., \& Cacioppo, J. T. (2012). Loneliness, health, and mortality in old age: A national longitudinal study. Social Science and Medicine, 74(6), 907-914. https://doi.org/10.1016/j.socscimed.2011.11.028

Lykes, V. A., \& Kemmelmeier, M. (2014). What predicts loneliness? cultural difference between individualistic and collectivistic societies in Europe. Journal of Cross-Cultural Psychology, 45(3), 468-490. https://doi.org/10.1177/0022022113509881

Maes, M., Qualter, P., Vanhalst, J., Van den Noortgate, W., \& Goossens, L. (2019). Gender differences in loneliness across the lifespan: A meta-analysis. European Journal of Personality, 33(6), 642-654. https://doi.org/10.1002/per.2220

Moeller, R. W., \& Seehuus, M. (2019). Loneliness as a mediator for college students' social skills and experiences of depression and anxiety. Journal of Adolescence, 73, 1-13. https://doi.org/10.1016/j.adolescence.2019.03.006

Ng, C. F., \& Northcott, H. C. (2015). Living arrangements and loneliness of South Asian immigrant seniors in Edmonton, Canada. Ageing and Society, 35(3), 552-575. https://doi.org/10.1017/S0144686X13000913

Patterson, A. C., \& Veenstra, G. (2010). Loneliness and risk of mortality: A longitudinal investigation in Alameda County, California. Social Science and Medicine, 71(1), 181186. https://doi.org/10.1016/j.socscimed.2010.03.024

Peltzer, K., \& Pengpid, S. (2019). Loneliness correlates and associations with health variables in the general population in Indonesia. International Journal of Mental Health Systems, 13(1), 1-11. https://doi.org/10.1186/s13033-019-0281-z

Phu, B., \& Gow, A. J. (2019). Facebook use and its association with subjective happiness and loneliness. Computers in Human Behavior, 92, 151-159. https://doi.org/10.1016/j.chb.2018.11.020

Pittman, M., \& Reich, B. (2016). Social media and loneliness: Why an Instagram picture may be worth more than a thousand Twitter words. Computers in Human Behavior, 62, 155-167. https://doi.org/10.1016/j.chb.2016.03.084

Shankar, A., McMunn, A., Banks, J., \& Steptoe, A. (2011). Loneliness, social isolation, and behavioral and biological health indicators in older adults. Health Psychology, 30(4), 377385. https://doi.org/10.1037/a0022826

Solano, C. H., Batten, P. G., \& Parish, E. A. (1982). Loneliness and patterns of self-disclosure. Journal of Personality and Social Psychology, 43(3), 524-531. https://doi.org/10.1037/0022-3514.43.3.524

Sukmaraga, I. G. B. G. (2018). Hubungan antara intensitas penggunaan media sosial Instagram dan materialisme pada remaja [Skripsi dipublikasikan, Universitas Sanata Dharma].

Vanhalst, J., Luyckx, K., Scholte, R. H. J., Engels, R. C. M. E., \& Goossens, L. (2013). Low selfesteem as a risk factor for loneliness in adolescence: Perceived - but not actual - social acceptance as an underlying mechanism. Journal of Abnormal Child Psychology, 41(7), 1067-1081. https://doi.org/10.1007/s10802-013-9751-y

Vodanovich, S. J. (2003). Psychometric measures of boredom: A review of the literature. Journal of Psychology: Interdisciplinary and Applied, 137(6), 569-595. https://doi.org/10.1080/00223980309600636

Whitfield, T., Lee, M., Barnhofer, T., Acabchuk, R., Lutz, A., Wirth, M., Coll-padros, N., Schlosser, M., \& Moulinet, I. (2020). The effect of mindfulness-based programs on cognitive performance across the lifespan: A systematic review and meta-analysis. 16, 12. https://doi.org/10.1002/alz.043562 
Widodo, M. K. D. N. (2015). Mindfulness sebagai mediator dalam hubungan antara kelekatan pada ibu dan self-silencing pada remaja laki dan perempuan [Skripsi dipublikasikan, Universitas Sanata Dharma].

Yang, C. C. (2016). Instagram use, loneliness, and social comparison orientation: Interact and browse on social media, but don't compare. Cyberpsychology, Behavior, and Social Networking, 19(12), 703-708. https://doi.org/10.1089/cyber.2016.0201

Yavich, R., Davidovitch, N., \& Frenkel, Z. (2019). Social media and loneliness-forever connected?. Higher Education Studies, 9(2), 10. https://doi.org/10.5539/hes.v9n2p10 